\title{
Evaluation of ETICS Characteristics that Affect Surface Mould Development
}

\author{
João L. Parracha ${ }^{1,2}$, Armand Cortay ${ }^{1,3}$, Giovanni Borsoi ${ }^{2}$, Rosário Veiga ${ }^{1}$ and Lina \\ Nunes ${ }^{1,4}$ \\ ${ }^{1}$ National Laboratory for Civil Engineering, LNEC, Av. do Brasil 101, Lisbon, Portugal, \\ jparracha@Inec.pt, rveiga@lnec.pt, linanunes@lnec.pt \\ ${ }^{2}$ Civil Engineering Research and Innovation for Sustainability, CERIS, Instituto Superior Técnico, \\ University of Lisbon, 1049-001, Lisbon, Portugal, giovanni.borsoi@tecnico.ulisboa.pt \\ ${ }^{3}$ École Nationale D’Ingénieurs de Saint-Étienne, ENISE, Rue Jean Parot 58, Saint-Étienne, France \\ armand.cortay@enise.fr \\ ${ }^{4}$ Centre for Ecology, Evolution and Environmental Changes, CE3C, Rua Capitão João d'Ávilla, \\ Azores, Portugal
}

\begin{abstract}
External Thermal Insulation Composite Systems (ETICS) are nowadays often used in new constructions but are also one of the most frequently used thermal retrofitting solutions for buildings. These systems have several advantages such as low installation cost, ease of application and increased thermal efficiency. Nevertheless, a number of questions have been raised on their long-time durability particularly related to biodeterioration. Biological growth is strongly influenced by several parameters, such as water content, temperature, $\mathrm{pH}$ but also by the type and hygroscopic properties of the building materials. It is therefore essential to understand and correlate those properties with biological growth. This paper aims at evaluating some ETICS characteristics that might influence surface mould development which is recognized as one of the major groups of deteriorating organisms. The susceptibility of the surface finishing layer and thermal insulation to biological growth was assessed through natural inocula and selected fungi and, whenever possible, correlated with water absorption and drying capacity. This study is part of a wider research project: WGB_Shield (Shielding building' facades on cities revitalization. Triple-resistance for water, graffiti and biocolonization of external thermal insulation systems) that aims at the development of ETICS with improved durability in the urban environment. Further development on this issue are ongoing.
\end{abstract}

Keywords: ETICS, Durability, Mould Growth, Water Performance, ETAG 004.

\section{Introduction}

The External Thermal Insulation Composite Systems (ETICS) are nowadays often used in Europe for new constructions and for thermal refurbishment of building facades (Barreira and Freitas, 2013). These systems present several advantages in comparison with other insulation solutions, such as the correction of thermal bridges, reduction of interior water condensation and increase of thermal efficiency, while maintaining the aesthetic appearance of the building, with relatively low installation cost and ease of application (Simona et al., 2017). Nevertheless, biological growth has been identified as one of ETICS main disadvantages, with several ETICS facades showing this problem only few years after the building construction/intervention (Johansson et al., 2010). Over time, biological growth causes cladding defacement, though it might not have major influence on the thermal performance of the system itself, however, 
altering the aesthetic appearance of the building. This situation commonly leads to a disapproval of the building owner, ending up with several economic and social consequences, that limit the full implementation and a wider diffusion of ETICS (Johansson et al., 2010).

Factors influencing mould growth on ETICS include nutrient availability, temperature, $\mathrm{pH}$ and moisture which seems to be the key factor (Johansson et al., 2012). Extensive fungal development is linked to high levels of surface moisture content, resulting from the combined effect of surface condensation, drying process as well as from the finishing render composition. When the drying process is slow, the surface moisture content remains high for long periods, increasing the risk of biocolonization (Barreira and de Freitas, 2013). Thus, the main parameters affecting biological colonization on ETICS are thought to be the composition of the different elements (insulation material, base coat mortar and finishing coat) and the behaviour of the system concerning water absorption and drying. It is therefore essential to understand the hygrometric properties of ETICS and their composition in order to correlate them with biological growth.

\section{Materials and Methods}

\subsection{Materials}

Seven different ETICS solutions from three different manufactures were tested for mould growth and water behavior (capillary absorption and drying capacity). Table 1 briefly describes

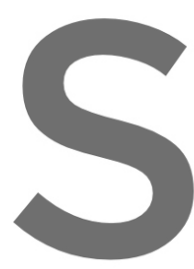
the selected materials. available due to industrial conficer

System (S)/ Thermal
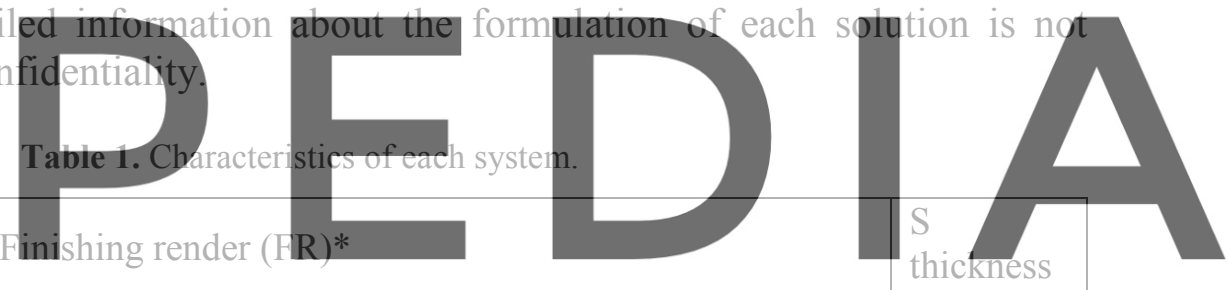

Finishing $(\mathrm{mm})=$

\begin{tabular}{|c|c|c|c|c|c|c|}
\hline \multirow{2}{*}{ (M) } & \multirow{2}{*}{ (TI) } & & \multirow{2}{*}{$\begin{array}{l}\text { thickness } \\
+ \text { FR } \\
\text { thickness }\end{array}$} \\
\hline & & Binder & Aggregates & $\begin{array}{l}\text { Admixtures } \\
\text { and additives }\end{array}$ & Coating & \\
\hline S1 / M1 & EPS-1 & Cement & \multirow{2}{*}{$\begin{array}{l}\text { Mineral } \\
\text { fillers and } \\
\text { resins }\end{array}$} & \multirow[t]{5}{*}{$\begin{array}{l}\text { Not } \\
\text { identified }\end{array}$} & \multirow[t]{2}{*}{ Acrylic paint } & $\begin{array}{l}\text { S: } 40.57 \\
\text { TI: } 35.29\end{array}$ \\
\hline S2 / M1 & EPS-1 & Cement & & & & $\begin{array}{l}\text { S: } 40.44 \\
\text { TI: } 35.29\end{array}$ \\
\hline $\mathrm{S} 3$ / M2 & ICB & $\begin{array}{l}\text { Lime }+ \\
\text { hydraulic } \\
\text { binders }\end{array}$ & $\begin{array}{l}\text { Mineral } \\
\text { fillers }\end{array}$ & & \multirow[b]{2}{*}{$\begin{array}{l}\text { Acrylic paint } \\
+ \text { pigment }\end{array}$} & $\begin{array}{l}\text { S: } 63.61 \\
\text { TI: } 59.73\end{array}$ \\
\hline $\mathrm{S} 4$ / M2 & EPS-2 & Cement & $\begin{array}{l}\text { Mineral } \\
\text { fillers, } \\
\text { resins, and } \\
\text { synthetic } \\
\text { fibres }\end{array}$ & & & $\begin{array}{l}\text { S: } 65.45 \\
\text { TI: } 59.99\end{array}$ \\
\hline S5 / M3 & ICB & $\begin{array}{l}\text { Natural } \\
\text { hydraulic } \\
\text { lime }+\end{array}$ & \begin{tabular}{|l} 
Acrylic \\
resins and \\
mineral \\
\end{tabular} & & $\begin{array}{l}\text { Acrylic with } \\
\text { siloxane } \\
\text { resins }\end{array}$ & $\begin{array}{l}\text { S: } 41.91 \\
\text { TI: } 37.91\end{array}$ \\
\hline
\end{tabular}




\begin{tabular}{|l|l|l|l|l|l|l|}
\hline & & $\begin{array}{l}\text { Mixed } \\
\text { binders }\end{array}$ & fillers & & & \\
\hline S6 / M3 & EPS-2 & $\begin{array}{l}\text { Cement }+ \\
\text { Mixed } \\
\text { binders }\end{array}$ & & & & $\begin{array}{l}\text { S: } 43.30 \\
\text { TI: } 38.30\end{array}$ \\
\hline S7 / M3 & MW & & & $\begin{array}{l}\text { S: } 44.80 \\
\text { TI: } 39.80\end{array}$ \\
\hline
\end{tabular}

EPS: expanded polystyrene; ICB: expanded cork; MW: mineral wool. EPS-1 and EPS-2 were produced by different manufactures. *The FR includes a biocide

Two types of samples were cut from the original ETICS panels of each system: the first was a set of 3 samples of each system with dimensions of $40 \mathrm{~mm} \times 40 \mathrm{~mm} \times \mathrm{S}$ thickness (Tab. 1), which was used to assess mould growth; the other is described in Table 2 and was used to assess capillary absorption and drying capacity of each system. The total thickness of each system ranges between $40.44 \mathrm{~mm}$ and $65.45 \mathrm{~mm}$ and is presented in Table 1. The thermal insulation materials of each solution were also individually tested for mould growth. There are four types of insulation materials, including mineral wool (MW), expanded polystyrene from two different manufactures (EPS-1 and EPS-2) and expended cork (ICB). The dimensions of these samples are $40 \mathrm{~mm} \times 40 \mathrm{~mm} \times \mathrm{TI}$ thickness (Tab. 1$)$.

Table 2. Materials, samples and laboratory tests for water behavior assessment.

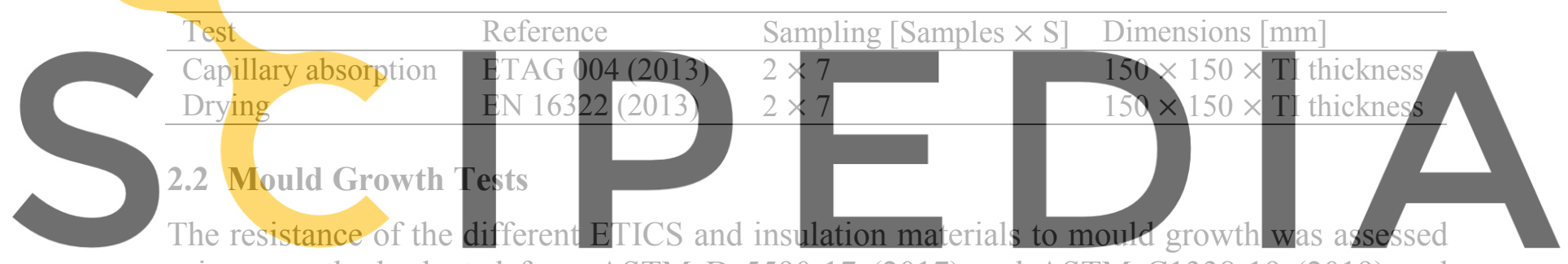

using a method adapted from ASTM D 5590-17 (2017) and ASTM C1338-19 (2019) and

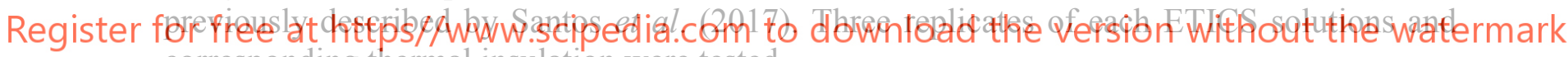
corresponding thermal insulation were tested.

Three fungal species were used in this study: spore suspensions of Aspergillus niger and

Penicillium funiculosum, applied together, and Aureobasidium pullulans, applied alone. These species were chosen due to their widespread presence in interior and outdoor environments and commonly referenced in the literature and standards (Hoang et al., 2010; ASTM D 5590-17, 2017; Verdier et al., 2014). A volume of $2 \mathrm{ml}$ of each spore suspension was uniformly distributed on the surface of the previously sterilized specimens and controls and the surrounding culturing media ( $4 \%$ malt, $2 \%$ agar). The controls were 3 replicates of Whatman $\mathrm{n}^{\circ} 1$ filter paper ( $45 \mathrm{~mm}$ diameter) and 3 wood samples (Pinus pinaster) with dimensions 40 $\mathrm{mm} \times 40 \mathrm{~mm} \times 10 \mathrm{~mm}$, that allowed the validation of the test (ASTM C1138-19, 2019). After inoculation, the test flasks were incubated at a temperature of $22 \pm 1{ }^{\circ} \mathrm{C}$ and $70 \pm 5 \% \mathrm{RH}$ for a period of four weeks. A third group of test specimens was exposed in the same conditions but without any sterilization or inoculation thus allowing their natural inocula to potentially develop. Each week, the samples were visually rated for mould growth using the scale defined in Table 3. At the end of the exposure period the samples were removed from the flasks and the final percentage of contaminated surface (Table 3) was evaluated with the help of a stereo microscope. 
João L. Parracha, Armand Cortay, Giovanni Borsoi, Rosário Veiga and Lina Nunes

Table 3. Rate of fungal (mould) development as defined in ASTM D 5590-17 (2017).

\begin{tabular}{lll}
\hline Rating & Description & Percentage of contaminated surface \\
\hline 0 & None & $0 \%$ \\
1 & Traces of growth & $<10 \%$ \\
2 & Light growth & 10 to $30 \%$ \\
3 & Moderate growth & 30 to $60 \%$ \\
4 & Heavy growth & $>60 \%$ \\
\hline
\end{tabular}

\subsection{Capillary Absorption and Drying Tests}

Water performance of ETICS was assessed through capillary absorption and drying capacity.

Capillary absorption tests were performed according to ETAG 004 (EOTA, 2013) in a conditioned room $\left(\mathrm{T}=23 \pm 2^{\circ} \mathrm{C}\right.$ and $65 \pm 5 \% \mathrm{RH}$ ). A total of four cycles (each cycle has $24 \mathrm{~h}$ with measurements at $3 \mathrm{~min}, 1,4,8$ and $24 \mathrm{~h}$ ) of capillary absorption were conducted. Capillary water absorption coefficient was obtained by the slope of the initial phase of the curve that expresses the water absorption as a function of square root of time.

Drying test was performed following the recommendations of EN 16322 (2013) and started immediately after the capillarity test. The test was performed in a conditioned room $\left(23 \pm 2^{\circ} \mathrm{C}\right.$ and $65 \pm 5 \%$ RH). Samples were weighted after determined periods of time until the variation of mass was constant for all samples. Two drying phases were determined: DR1 - the first drying phase, obtained by the negative slope of the initial linear section of the drying curve plotted with time in abscissa; and DR2 - the second drying phase, calculated by the negative slope of the linear sectio Drying index (DI) was registered during the the mass of the sample of the drying process
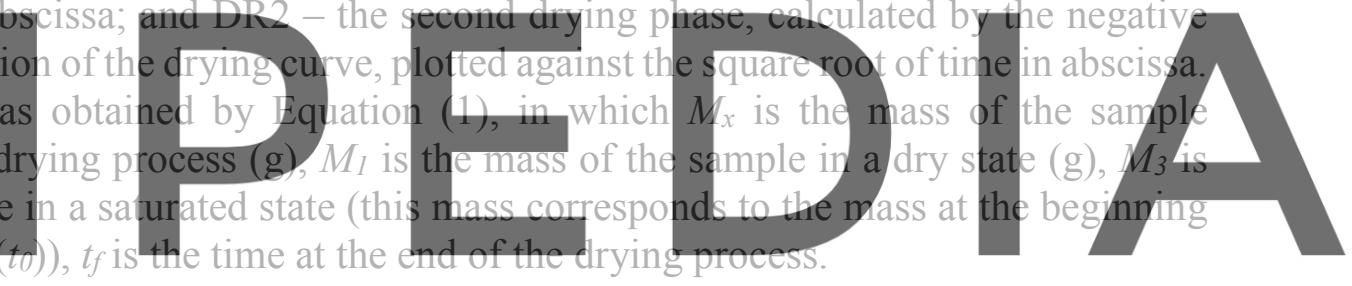

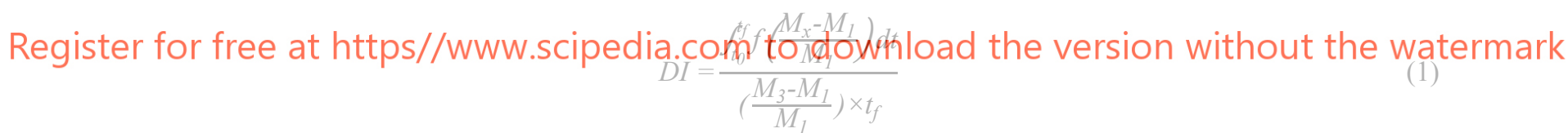

\section{Results and Discussion}

\subsection{Resistance to Mould Growth}

The results of the average rate of mould growth for ETICS surface finishing layer considering all type of inoculation were the same during or at the end of the test: zero (no growth). All controls (Whatman $n^{\circ} 1$ filter paper and wood) were rated as 4 at the end of the 4-week testing which confirms the validity of the procedure. The fact that no growth occurs for any ETICS surface after 4 weeks of testing can be explained by the presence of biocide on the finishing render. Nevertheless, these are newly produced, unaltered sound systems, which were not subjected to any kind of aging or weathering procedures.

The results of the average rate of mould growth for the insulation materials are shown in Figure 1. After 4 weeks of incubation, significant mould growth was observed on the ICB samples, rated as 2 or more for every type of inocula (natural or artificial). For EPS-1 samples, 
no growth was reported at any time during the test, however, for EPS-2, some samples presented traces of growth, especially with natural inocula. MW samples presented no growth for the $A$. pullulans inoculation and traces of growth since the first week of observations for the A. niger and $P$. funiculosum inoculation. Only one of the three MW tested samples showed traces of growth (rated as 1) after 4 weeks testing for natural inocula.
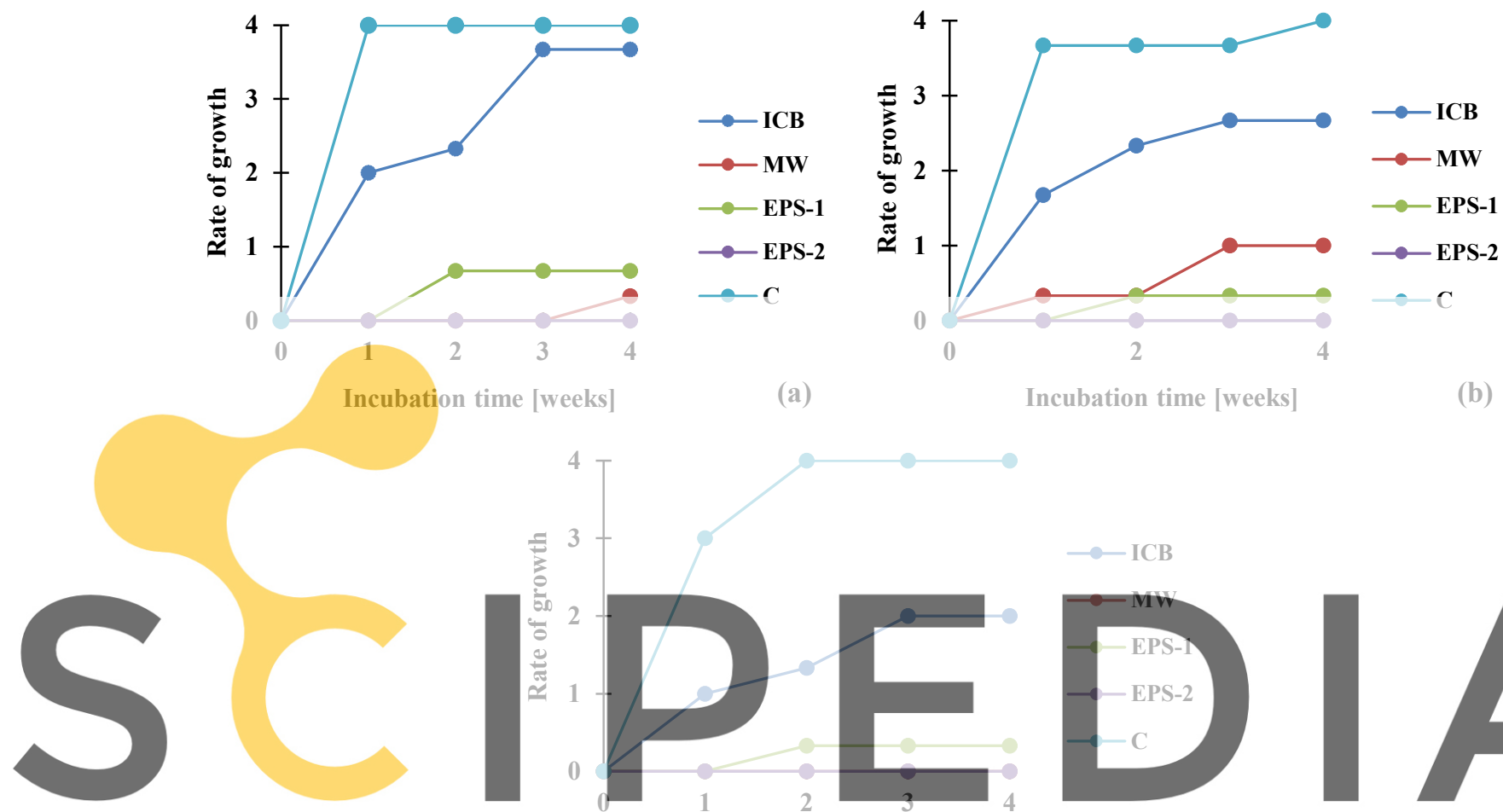

(a)

Incubation time [weeks]

(b)

\section{Register for}

free at https//www.scipedia.com to download the version without the watermark Figure 1. Results of the average rate of mould growth for the insulation materials considering: (a) natura

inocula (b) artificial inoculation with $A$. niger and $P$. funiculosum (c) artificial inoculation with A. pullulans.

Amongst the insulation materials, ICB samples presented the most intense mould growth. In fact, cork is a natural organic material with suberin, lignin and polysaccharides (cellulose and hemicellulose) in its composition (Knapic et al., 2016). Organic or organic-based materials are more vulnerable to fungal deterioration since they provide ample nutrients, through their composition, contributing to fungal growth (Klamer et al., 2004; Hoang et al., 2010). Additionally, the results of rate of growth for ICB were significantly higher when inoculated with A. niger and P. funiculosum rather than A. pullulans.

In general, MW and EPS samples present a good resistance to mould attack, always presenting a rate of growth lower or equal to 1 . Concerning MW, as an inorganic material, the susceptibility to mould growth is naturally lower than that of organic materials. The only sample rated as 1 for natural inocula could have been previously contaminated with some organic dust particles, that contributed to the increase of mould growth susceptibility (Jerábková and Tesarová, 2018). Regarding EPS, the resistance to fungal growth is noteworthy, which is in accordance with the results obtained by Jerábková and Tesarová (2018). 
All insulation materials presented higher mould growth for natural inocula than for artificial inoculation. If, on the one hand, natural inocula can be more representative of real conditions (Hoang et al., 2010), artificial inoculation significantly accelerates the test while improving repeatability and comparison between materials (Johansson et al., 2012, 2014).

\subsection{Capillary Water Absorption and Drying}

The results obtained for capillary absorption and drying are shown in Table 4 and Figure 2. Sample S3 presents the highest value of capillary absorption at $1 \mathrm{~h}$ and $24 \mathrm{~h}$, whereas sample S1 presents the lowest values. In fact, samples S1 and S2, both with cement-based matrix in the base coat and from the same manufacturer, presented lowest capillary water absorption, and, as a consequence of low water content, also the fastest drying capacity. Sample S1 presented not only the lowest values of capillary absorption at $1 \mathrm{~h}$ and $24 \mathrm{~h}$ but also the lowest value of capillary water absorption coefficient.
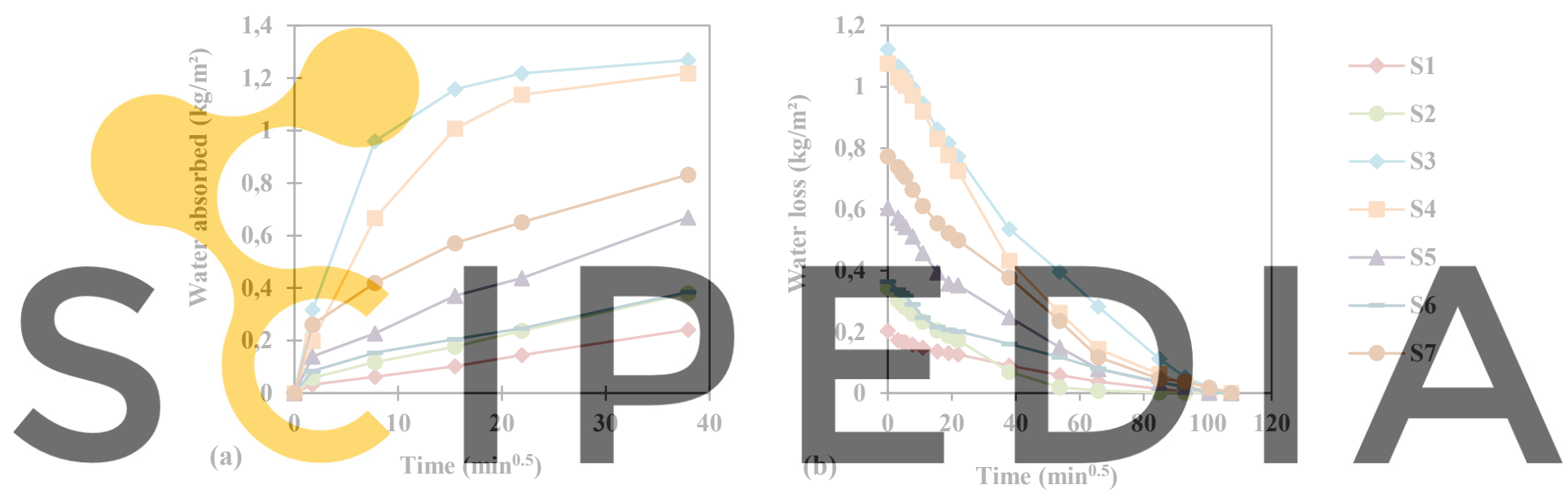

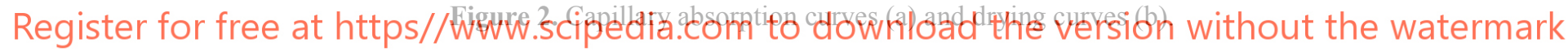

By comparing the capillary water absorption coefficient (C) obtained for sample S5 and S6, it was noticed an increase of $65 \%$ of the value of $\mathrm{C}$ for $\mathrm{S} 5$ in relation to S6. These samples present the same composition of finishing render with exception of the binder ( 55 has natural hydraulic lime and mixed binders while S6 is composed of cement and mixed binders).

All samples achieved values of capillary absorption after $1 \mathrm{~h}$ testing that are lower than 1 $\mathrm{kg} / \mathrm{m}^{2}$, which is the value required by ETAG 004 (EOTA, 2013). In fact, for all tested solutions, the highest level of capillary absorption happens in the first hour of test (even in the first $3 \mathrm{~min}$ ), followed by a stabilization of the capillary water absorption. Therefore, all solutions have an adequate performance with regards to capillary absorption and drying, presenting low values of capillary absorption.

The results obtained for drying test are in line with those obtained for capillary water absorption, since samples that generally absorb more water are those that present higher drying rates, allowing fast removal of absorbed water. Additionally, a high correlation was obtained between the capillary absorption coefficient and drying rate $2\left(\mathrm{R}^{2}=0.77\right)$. 
João L. Parracha, Armand Cortay, Giovanni Borsoi, Rosário Veiga and Lina Nunes

Table 4. Capillary absorption and drying test results.

\begin{tabular}{|c|c|c|c|c|c|c|c|}
\hline \multirow[b]{2}{*}{$\begin{array}{l}\text { System } \\
\text { (S) }\end{array}$} & \multicolumn{4}{|c|}{ Capillary absorption } & \multicolumn{3}{|c|}{ Drying } \\
\hline & $\begin{array}{l}\text { Capillary } \\
\text { absorption } \\
1 \mathrm{~h} \\
\left(\mathrm{~kg} / \mathrm{m}^{2}\right)\end{array}$ & $\begin{array}{l}\text { ETAG } \\
004(\leq 1 \\
\mathrm{kg} / \mathrm{m}^{2} \text { at } \\
1 \mathrm{~h})\end{array}$ & $\begin{array}{l}\text { Capillary } \\
\text { absorption } \\
24 \mathrm{~h} \\
\left(\mathrm{~kg} / \mathrm{m}^{2}\right)\end{array}$ & $\begin{array}{l}\mathrm{C} \\
\left(\mathrm{kg} / \mathrm{m}^{2} \cdot \min ^{0.5}\right)\end{array}$ & $\begin{array}{l}\text { DR1 } \\
\left(\mathrm{kg} / \mathrm{m}^{2} \cdot \mathrm{h}\right)\end{array}$ & $\begin{array}{l}\text { DR2 } \\
\left(\mathrm{kg} / \mathrm{m}^{2} \cdot \mathrm{h}^{0.5}\right)\end{array}$ & DI \\
\hline S1 & 0.062 & $\sqrt{ }$ & 0.242 & 0.019 & 0.0030 & 0.0197 & 1.05 \\
\hline S2 & 0.118 & $\sqrt{ }$ & 0.379 & 0.034 & 0.0068 & 0.0396 & 1.02 \\
\hline S3 & 0.959 & $\sqrt{ }$ & 1.268 & 0.184 & 0.0151 & 0.0989 & 1.01 \\
\hline S4 & 0.667 & $\sqrt{ }$ & 1.217 & 0.115 & 0.0169 & 0.1099 & 0.94 \\
\hline S5 & 0.227 & $\sqrt{ }$ & 0.669 & 0.081 & 0.0095 & 0.0619 & 1.00 \\
\hline S6 & 0.154 & $\sqrt{ }$ & 0.385 & 0.049 & 0.0051 & 0.0335 & 1.00 \\
\hline S7 & 0.419 & $\sqrt{ }$ & 0.832 & 0.151 & 0.0111 & 0.0773 & 0.98 \\
\hline
\end{tabular}

\section{Conclusions}

With the aim of evaluating the resistance of different ETICS surface finishing layer and insulation materials to mould growth under laboratory conditions, 7 different ETICS solutions were tested considering three different types of inoculation. The thermal insulation materials of each solution were also individually tested for mould growth. Additionally, capillary water absorption and drying capacity of each ETICS were assessed.

The main conclusions of this study are the following:

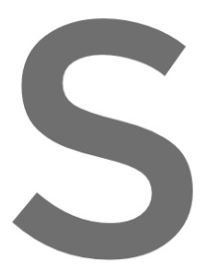
No mould growth was detected on any ETICS surface fi-
though it should be noticed that the materials were te
weathering procedures.
Considering the thermal insulation materials tested ind
samples were the ones obtaining the highest level of nishing layer after $4-v$
ested without previou
mould growth after -week testing
growth, ICB
er 4 -week of incubation. For EPS-1 samples, no growth was reported at any time during the test.

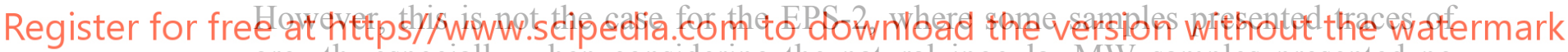
growth, especially when considering the natural inocula. MW samples presented no growth for the A. pullulans inoculation but traces of growth for the mixed spore suspension. However, as stated in the previous point, these differences in the insulation materials didn't visibly affect the full system behavior.

- All insulation materials presented higher mould growth for natural inocula than for artificial inoculation with either of the spore suspensions.

- All tested ETICS solutions showed good performance regarding capillary water absorption and drying capacity, with all solutions accomplishing the ETAG 004 requirements. Such good characteristics could be one of the reasons why, at this stage, the susceptibility of some insulation materials to mould growth didn't affect the performance of the full system. However, further tests are necessary to assess the moisture transport properties of ETICS after natural and artificial aging and compare those values with the ones presented in this study.

The results obtained in the present study give an overview on ETICS characteristics (capillary absorption, drying capacity and composition of ETICS layers) that might affect surface mould development. The next step in the research will consist on verifying ETICS durability by natural and artificial aging tests, which will affect ETICS finishing coat, possibly 
leading to a higher susceptibility of the system to mould growth.

\section{Acknowledgements}

The authors gratefully acknowledge the support given by Portuguese Foundation for Science and Technology (FCT) within research project PTDC/ECI-EGC/30681/2017 (WGB_Shield - Shielding building' facades on cities revitalization. Triple resistance for water, graffiti and biocolonization of external thermal insulation systems).

\section{ORCID}

João Luís Parracha: https://orcid.org/0000-0001-6214-3400

Giovanni Borsoi: https://orcid.org/0000-0002-2194-4620

Maria do Rosário Veiga: https://orcid.org/0000-0002-7135-8603

Lina Nunes: https://orcid.org/0000-0001-6849-3241

\section{References}

ASTM D 5590-17 (2017). Determining the resistance of paint films and related coatings to fungal defacement by accelerated four-week agar plate assay. ASTM International, Pennsylvania, USA

ASTM C1338-19 (2019). Standard test method for determinig fungi resistance of insulation materials and facings. ASTM International, Pennsylvania, USA

Barreira, E. and Freitas, V.P. (2013). Experimental study of the hygrothermal behaviour of External Thermal Insulation Composite Systems (ETICS). Building and Environment, 63, 31-39. doi: 10.1016/j.buildenv.2013.02.001

EN 16322 (2013). Conservation of Cultural Heritage - Test methods - Determination of drying properties. European Committee for Standardization, Brussels, Belgium

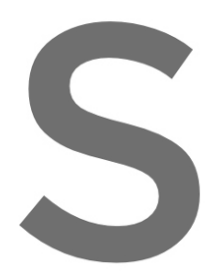

EOTA (2013). Guideline for rendering. ETAG 004 Brussels, Be

Hoang, C.P., Kinney, K.A., C. growth. International Bia

Jerábková, E. and Tesaroy to growth of microorganisms. W
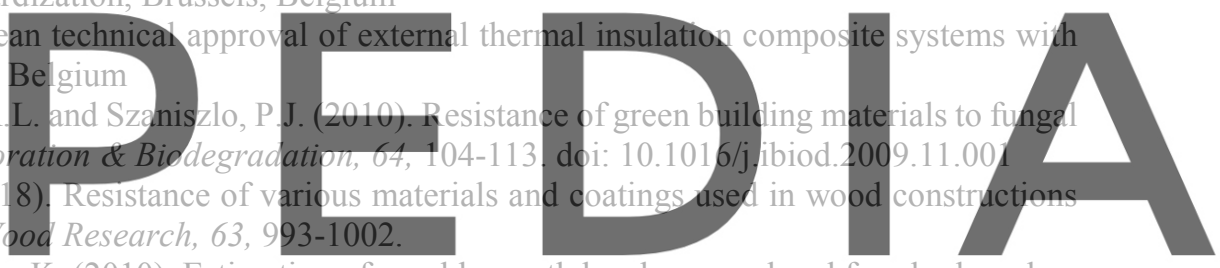

Johansson, S., Wadsö, L. and Sandin, K. (2010). Estimation of mould growth levels on rendered façades based on surface relative humidity and surface temperature measurements. Building and Environment, 45, 1153-1160.

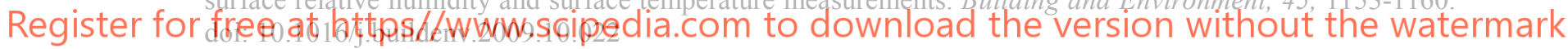

Johansson, P., Ekstrand-Tobin, A., Svensson, T. and Bok, G. (2012). Laboratory study to determine the critical moisture level for mould growth on building materials. International Biodeterioration \& Biodegradation, 73, 23-32. doi: 10.1016/j.ibiod.2012.05.014

Johansson, P., Ekstrand-Tobin, A. and Bok, G. (2014). An innovative test method for evaluating the critical moisture level for mould growth on building materials. Building and Environment, 81, 404-409. doi: 10.1016/j.buildenv.2014.07.002

Klamer, M., Morsing, E. and Husemoen, T. (2004). Fungal growth on different insulation materials exposed to different moisture regimes. International Biodeterioration \& Biodegradation, 54, 277-282. doi: 10.1016/j.ibiod.2004.03.016

Knapic, S., Oliveira, V., Machado J.S. and Pereira H. (2016). Cork as a building material: a review. European Journal of Wood and Wood Products, 74, 775-791. doi: 10.1007/s00107-016-1076-4

Santos, T., Nunes, L. and Faria P. (2017). Production of eco-efficient earth-based plasters: Influence of composition on physical performance and bio-susceptibility. Journal of Cleaner Production, 167, 55-67. doi: 10.1016/j.jclepro.2017.08.131

Simona, P.L., Spiru, P. and Ion, I.V. (2017). Increasing the energy efficiency of buildings thermal insulation. Energy Procedia, 128, 393-399. doi: 10.1016/J.EGYPRO.2017.09.044

Verdier, T., Coutand, M., Bertron, A. and Roques, C. (2014). A review of indoor microbial growth across building materials and sampling and analysis methods. Building and Environment, 80, 136-149. doi: 10.1016/j.buildenv.2014.05.030 